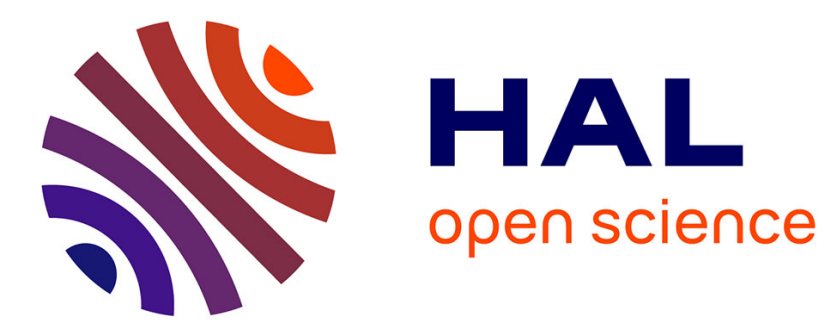

\title{
Dislocation multiplication in GaAs : inhibition by doping
}

\author{
A. Djemel, J. Castaing, N. Burle-Durbec, B. Pichaud
}

\section{To cite this version:}

A. Djemel, J. Castaing, N. Burle-Durbec, B. Pichaud. Dislocation multiplication in GaAs: inhibition by doping. Revue de Physique Appliquée, 1989, 24 (8), pp.779-793. 10.1051/rphysap:01989002408077900 . jpa-00246101

\section{HAL Id: jpa-00246101 https://hal.science/jpa-00246101}

Submitted on 1 Jan 1989

HAL is a multi-disciplinary open access archive for the deposit and dissemination of scientific research documents, whether they are published or not. The documents may come from teaching and research institutions in France or abroad, or from public or private research centers.
L'archive ouverte pluridisciplinaire HAL, est destinée au dépôt et à la diffusion de documents scientifiques de niveau recherche, publiés ou non, émanant des établissements d'enseignement et de recherche français ou étrangers, des laboratoires publics ou privés. 


\title{
REVUE DE PHYSIQUE APPLIQUÉE
}

Revue Phys. Appl. 24 (1989)779-793

AOUT 1989, PAGE 779

Classification

Physics Abstracts

$61.70-81.10$

\section{Dislocation multiplication in GaAs : inhibition by doping}

\author{
A. Djemel $\left({ }^{1, *}\right)$, J. Castaing $\left({ }^{1}\right)$, N. Burle-Durbec $\left({ }^{2}\right)$ and B. Pichaud $\left({ }^{2}\right)$ \\ ( $\left.{ }^{1}\right)$ Laboratoire de Physique des Matériaux C.N.R.S. Bellevue, 92195 Meudon Cedex, France \\ $\left(^{2}\right)$ Laboratoire de Physique Cristalline, Unité associée au C.N.R.S. n ${ }^{\circ} 797$, Faculté des Sciences de St- \\ Jérôme, 13397 Marseille Cedex 13, France
}

(Reçu le 3 janvier 1989, accepté le 9 mai 1989)

\section{Overview article}

\begin{abstract}
Résumé. - L'amélioration de la qualité cristalline par dopage électrique ou isoélectronique des cristaux de GaAs obtenus par la méthode L.E.C. est reliée aux modèles thermoélastiques donnant les contraintes en cours de croissance. On en déduit les structures de dislocations dans les cristaux bruts de croissance et recuits, en particulier à la lumière des résultats de déformation plastique. L'addition de différents éléments des colonnes II-III-IV-V-VI dans GaAs est envisagée et son influence sur les mécanismes d'établissement de la sousstructure de dislocations est discutée.
\end{abstract}

\begin{abstract}
The crystal quality improvement by electrical or isoelectronic doping of L.E.C. grown GaAs crystals is related to the thermoelastic modelling of stresses during growth. The dislocation structure in asgrown and annealed crystals is deduced, in particular with the help of the results of plastic deformation. The addition of various elements of the columns II-III-IV-V-VI in GaAs is considered and its influence on the establishment of the dislocation substructure is discussed.
\end{abstract}

\section{Introduction.}

Large semi-insulating (S.I.) single crystals of gallium arsenide generally contain a high density of dislocations $\left(10^{4}\right.$ to $\left.10^{5} \mathrm{~cm}^{-2}\right)$. These dislocations are regarded as a consequence of the large stresses undergone by the crystals during their growth by the liquid encapsulated Czochralski (L.E.C.) technique, which is the most commonly used. GaAs indeed, unlike silicon has a low mechanical strength, exhibiting a critical resolved shear stress (C.R.S.S.) five times smaller at $0.7 T_{\mathrm{M}}\left(T_{\mathrm{M}}\right.$ : melting temperature $)$ [1]. As dislocations are detrimental to device performancès, for instance they induce high leakage currents in field effect transistors [2], it is then interesting to control their presence in order to promote the development of GaAs integrated circuits technology. Dislocation density reduction in GaAs has been sought along two ways:

(i) to reduce the stresses by improving the thermal conditions in the L.E.C. systems [3], i.e. by changing

(*) Permanent address: Laboratoire de Physique du Solide, Université de Constantine, Algeria. the amount of encapsulant [4] or by using other growth techniques such as horizontal [5] or vertical Bridgmann [6]. A substantial reduction has not yet been achieved for applications ;

(ii) to increase the mechanical strength of GaAs by solid solution hardening with elements of the column II, III, IV, V or VI [7-11]. The dopants are, in some cases, efficient to reduce the dislocation density (Tab. I), but they modify the electrical characteristics of GaAs when they are not from the columns III or V. Doping with the isoelectronic indium gives remarquable results for concentrations higher than $8 \times 10^{19}$ at. $\mathrm{cm}^{-3}$; large S.I. GaAs single crystals have been grown, with zero dislocation which are suitable for device fabrication [12].

Why do undoped crystals contain dislocations ? How does alio - or isoelectronic doping improve the crystal quality of GaAs ? Is the C.R.S.S. raised by doping and what is the mechanism of hardening ? It can be solid solution hardening or more complex interactions due to Cottrell atmosphere or to the Suzuki effect, well known at medium and high temperatures. Is this sufficient to inhibit the dislo- 
Table I. - The effects of different doping elements in GaAs and their related parameters.

\begin{tabular}{|c|c|c|c|c|c|c|c|}
\hline $\begin{array}{l}\text { Type of } \\
\text { bonding }\end{array}$ & $\begin{array}{l}\text { Doping } \\
\text { element } \\
\quad X\end{array}$ & $\begin{array}{l}\text { Atomic } \\
\text { column }\end{array}$ & $\begin{array}{l}\text { Electrical } \\
\text { type }\end{array}$ & $\begin{array}{c}\text { Effect on } \\
\text { dislocation } \\
\text { density }\end{array}$ & $\begin{array}{c}\text { Efficient } \\
\text { concentration } \\
\left(\text { at.cm }{ }^{-3}\right)\end{array}$ & $\begin{array}{l}\text { Bonding energy } \\
\text { Ga-X or X-As } \\
\left(\mathrm{kJ} \cdot \mathrm{mol}^{-1}\right)\end{array}$ & $\begin{array}{l}\text { Lattice } \\
\text { mismatch } \\
(\%)\end{array}$ \\
\hline \multirow{3}{*}{$\begin{array}{c}\text { X-As } \\
\text { (substitution) } \\
\text { with Ga) }\end{array}$} & $\begin{array}{l}\mathrm{Zn} \\
\mathrm{Cd}\end{array}$ & $\begin{array}{l}\text { II } \\
\text { II }\end{array}$ & $\begin{array}{l}\mathrm{p} \\
\mathrm{p}\end{array}$ & $\begin{array}{l}0 \\
0\end{array}$ & - & $\begin{array}{l}353 \\
217\end{array}$ & $\begin{array}{r}+4.0 \\
+17.5\end{array}$ \\
\hline & $\begin{array}{l}\mathrm{B} \\
\mathrm{Al} \\
\mathrm{Ga} \\
\mathrm{In}\end{array}$ & $\begin{array}{l}\text { III } \\
\text { III } \\
\text { III } \\
\text { III }\end{array}$ & $\begin{array}{l}\text { iso } \\
\text { iso } \\
\text { iso }\end{array}$ & $\begin{array}{l}0 \\
+ \\
+ \\
++\end{array}$ & $\begin{array}{c}\overline{10^{19}} \\
-\overline{1} \\
8 \times 10^{19}\end{array}$ & $\begin{array}{l}305 \\
259 \\
199 \\
150\end{array}$ & $\begin{array}{c}-30.2 \\
0 \\
-\overline{14.3}\end{array}$ \\
\hline & $\begin{array}{l}\mathrm{Si} \\
\mathrm{Ge} \\
\mathrm{Sn}\end{array}$ & $\begin{array}{l}\text { IV } \\
\text { IV } \\
\text { IV }\end{array}$ & $\begin{array}{l}\mathrm{n} \\
\mathrm{n} \\
\mathrm{n}\end{array}$ & $\begin{array}{l}++ \\
+ \\
+\end{array}$ & $\begin{array}{c}10^{18} \\
? \\
?\end{array}$ & $\begin{array}{l}159 \\
150 \\
143\end{array}$ & $\begin{array}{r}-7.1 \\
-3.2 \\
+11.1\end{array}$ \\
\hline \multirow{2}{*}{$\begin{array}{c}\text { Ga-X } \\
\text { (substitution } \\
\text { with As) }\end{array}$} & $\begin{array}{l}\mathrm{N} \\
\mathrm{P} \\
\mathrm{As} \\
\mathrm{Sb}\end{array}$ & $\begin{array}{l}\text { V } \\
\text { V } \\
\text { V } \\
\text { V }\end{array}$ & $\begin{array}{l}\text { iso } \\
\text { iso } \\
\text { iso }\end{array}$ & $\begin{array}{l}+ \\
+ \\
+\end{array}$ & $\begin{array}{c}? \\
>10^{19} \\
- \\
2 \times 10^{19}\end{array}$ & $\begin{array}{l}405 \\
244 \\
199 \\
243\end{array}$ & $\begin{array}{c}-40.7 \\
-6.8 \\
-\overline{15.3}\end{array}$ \\
\hline & $\begin{array}{l}\mathrm{S} \\
\mathrm{Se} \\
\mathrm{Te}\end{array}$ & $\begin{array}{l}\text { VI } \\
\text { VI } \\
\text { VI }\end{array}$ & $\begin{array}{l}\mathrm{n} \\
\mathrm{n} \\
\mathrm{n}\end{array}$ & $\begin{array}{l}++ \\
++ \\
++\end{array}$ & $\begin{array}{c}2 \times 10^{18} \\
10^{18} \\
5 \times 10^{18}\end{array}$ & $\begin{array}{l}336 \\
291 \\
245\end{array}$ & $\begin{array}{r}-11.9 \\
-3.4 \\
+11.9\end{array}$ \\
\hline
\end{tabular}

cation multiplication during the growth of single crystals? These questions have not yet been addressed, in detail, in GaAs, by comparing the properties of deformed and as-grown materials. This global approach has been used recently in a short study on InP [13].

In the present paper, we aim to link the results obtained in various works on GaAs : growth, defect production and plastic deformation. We first describe the dislocation structure in as-grown crystals and the influence of doping and heat treatments. Thermoelastic modelling is then reviewed; it gives the stresses in GaAs boules during growth. Comparisons with flow stresses during plastic deformation allow to assess the importance of this phenomenon in the formation of dislocation structures in GaAs. The effect of impurities is also discussed.

\section{As-grown crystals : microstructure, influence of annealing.}

2.1 Dislocations IN UNDOPED CRYSTALS. - The microstructure of $\mathrm{GaAs}$ single crystals has been investigated at millimetric scale by X-ray topography, chemical etch pitting, infra-red light transmission and scattering (see [14] for review). These observations have been performed on single crystal slices cut parallel or perpendicular to the $\langle 001\rangle$ growth axis, as well as along $\{111\}$ slip planes.
Transmission electron microscopy (T.E.M.) has seldom been used.

S.I. or n-type undoped crystals obtained by the L.E.C. technique, generally display a cell structure (Fig. 1), similar to the one observed in metals after deformation at medium temperature [15], except for the cell size which ranges from 100 to $500 \mu \mathrm{m}$ in GaAs. The dislocation density is between $10^{4}$ and $10^{5} \mathrm{~cm}^{-2}$; isolated dislocations can be observed in the center of the cells. Well defined subgrain-boundaries can be seen along the radii of. slices cut perpendicular to the growth axis.

T.E.M. examination of the entangled walls of the cells has shown that they are made of standard dislocations belonging to the $a / 2\langle 110\rangle\{111\}$ slip system, with a large number of Lomer-Cottrell locks resulting from the interaction of various slip systems [16].

\subsection{MICROSTRUCTURE OF AS-GROWN DOPED CRYS- TALS.}

2.2.1 Macroscopic observations. - Doping with Te, $\mathrm{S}$, Se and Si yields a dislocation density reduction for increasing concentrations [7-9]. This improvement is spectacular above a threshold concentration (Fig. 2). For example, GaAs with sulphur or silicon is almost dislocation free for carrier concentrations higher than $10^{18} \mathrm{~cm}^{-3}$, which correspond to a $\mathrm{Si}$ concentration of $2 \times 10^{18} \mathrm{at}_{\mathrm{cm}} \mathrm{cm}^{-3}$. With zinc, p-type 

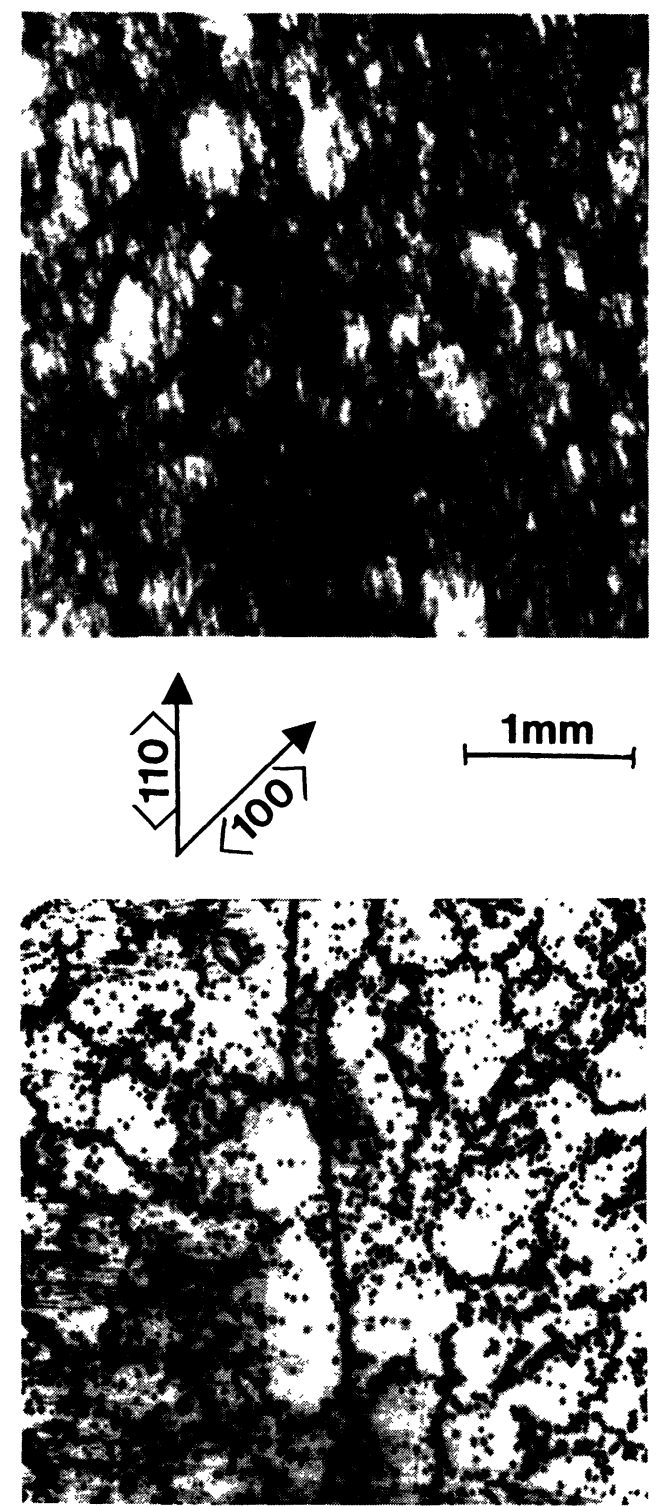

Fig. 1. - Revelation of the dislocation substructure in (001) undoped GaAs silice, (a) by X-ray topography, reflection 220, (b) by etch pitting (courtesy A. Chabli L.E.T.I., C.E.N. Grenoble, France).

GaAs does not display any improvement in crystal perfection; an increase in dislocation density has, even, been reported [17].

The same spectacular effect is observed with the isovalent indium dopant [18], where dislocation reduction is observed for In concentrations above $8 \times 10^{19}$ at. $\mathrm{cm}^{-3}$. Figure 3 illustrates this effect, with a set of observations on a slice cut parallel to the [001] growth axis of a $5 \mathrm{~cm}$ diameter boule with variable indium concentration; three different regions are evidenced :

(i) close to the seed where the indium concentration [In] is of the order of $5 \times 10^{19}$ at. $\mathrm{cm}^{-3}$, a high density of dislocation tangles can be observed (Fig. 3a) ;

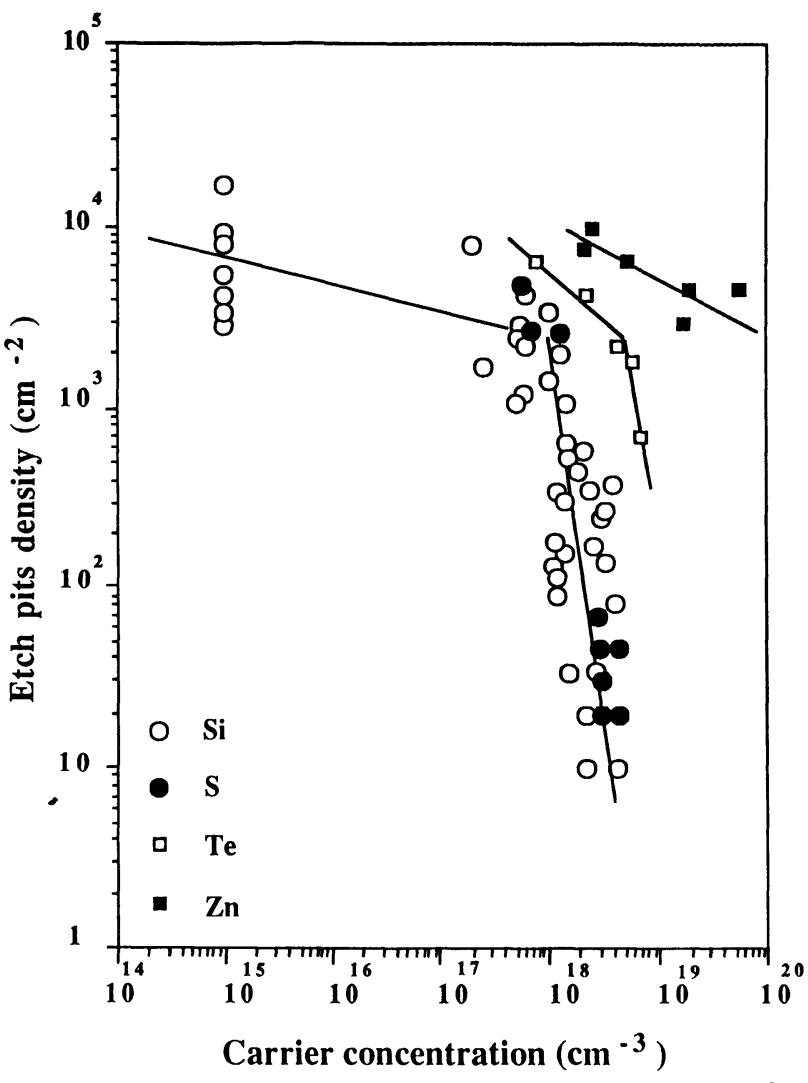

Fig. 2. - Variation of the etch pits density $v s$. carrier concentration in $\mathrm{GaAs}$ doped with $\mathrm{S}, \mathrm{Te}, \mathrm{Zn}$ [7] and $\mathrm{Si}$ [8].

(ii) at the other end of the crystal, where [In ] $>10^{20}$ at.cm ${ }^{-3} \mathrm{GaAs}$ is almost dislocation free (Fig. 3d) ;

(iii) for intermediate regions, with $[\operatorname{In}]=7$ to $9 \times 10^{19}$ at.cm $^{-3}$, dislocation bands, perpendicular to the growth axis, can be observed; between these bands, there is essentially no dislocation (Fig. 3b). The periodic variation of dislocation density occurs on $1 \mathrm{~mm}$ distances and is superimposed on the usual growth striations; it is attributed to indium fluctuations around the threshold concentration [18, 19].

In order to explain the mechanism of dislocation density reduction, the characteristics of residual dislocations have been determined in highly doped $\mathrm{GaAs}$, especially for $\mathrm{Si}$ and In doping. Various kinds of defects have been found [20] : dislocations emerging from the interface with the seed, glide dislocations, helical dislocations and others with unusual Burgers vectors [21, 22]. It can be noted that, for $\mathrm{Si}$ or In doped $\mathrm{GaAs}$, there is a relation between the amount of impurities and the shape of dislocations, suggesting that the extent of cross-slip or climb mechanisms depends on the impurity concentration. In figure 3, from b) to c) and d), one can notice that the complex configuration of dislocations evolves to segments confined in glide planes, which could mean that the presence of increasing amount of In (or Si) decreases the rate of climb or cross-slip. 

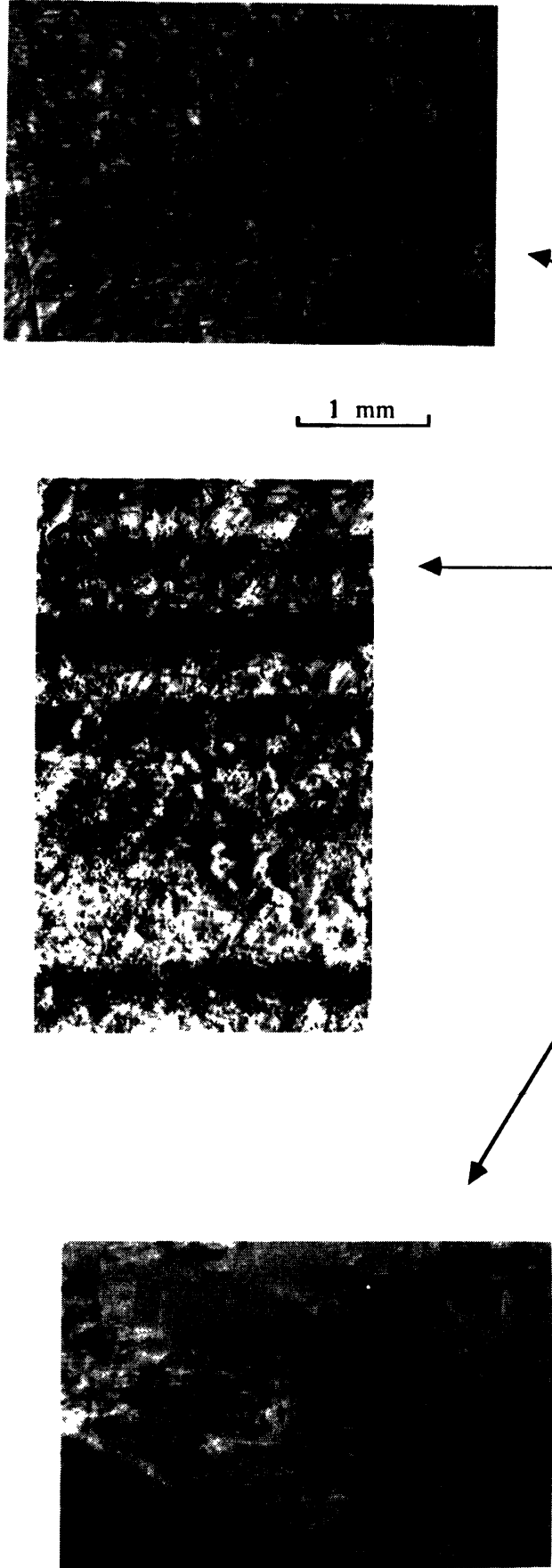

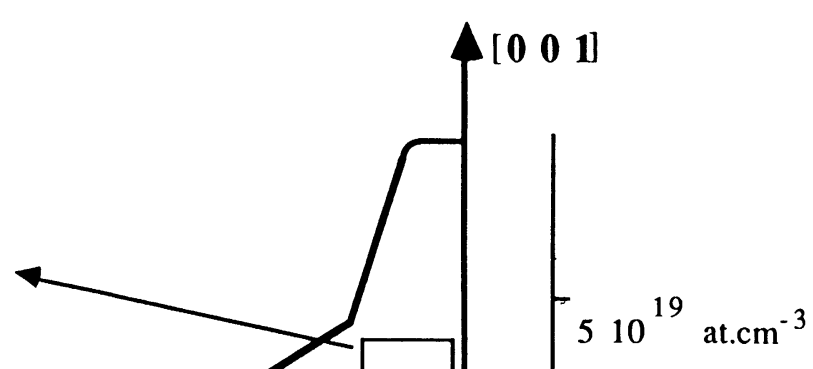

a

( 1110$)$

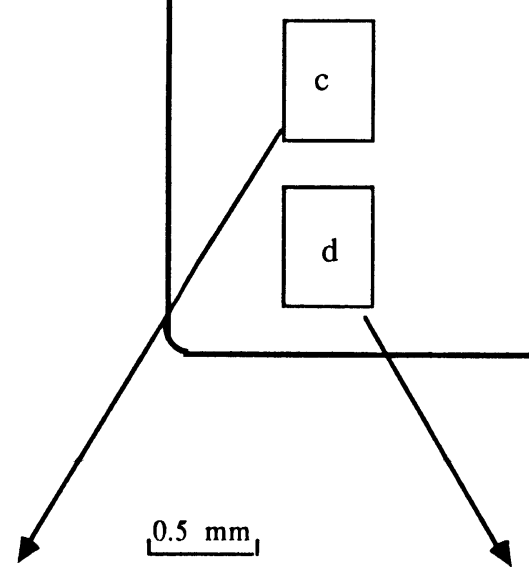

$1.510^{20}$ at.cm $^{-3}$

$810^{19}$ at. $^{-3}$

$10^{20}$ at.cm $^{-3}$

$\checkmark[\mathbf{I} n]$

Fig. 3. - Different types of dislocation substructures in a schematic In doped GaAs ingot as a function of In concentrations range, (110) slice observed by X-ray transmission topography, reflection 220 . (a) High density of entangled dislocations, (b) entangled dislocations alternately in high and low density, (c) low density of dislocations with non planar geometries, (d) dislocations lying in the same $\{111\}$ plane.

2.2.2 Microscopic observations. - A great variety of defects are observed by T.E.M. in as-grown GaAs containing large amounts of electrically active dopants : stacking faults, microprecipitates, interstitial or vacancy dislocation loops. For instance, in Te doped GaAs, Laister et al. [23, 24] have found wide stacking faults when the Te concentration exceeds $10^{18}$ at. $\mathrm{cm}^{-3}$. Their number increases with the Te content and precipitates appear above $10^{19}$ at. $\mathrm{cm}^{-3}$.
For In doped GaAs, no specific feature has been mentioned after T.E.M. observations [25].

\subsection{MiCROSTRUCTURE OF ANNEALED DOPED CRYS-} TALS. - After annealing at various temperatures, the defects present in Te doped GaAs single crystals display different behaviours [23, 24, 26, 27], which are schematically represented in figure 4 :

(i) below $400{ }^{\circ} \mathrm{C}$ and above $1080^{\circ} \mathrm{C}$, no loop and 


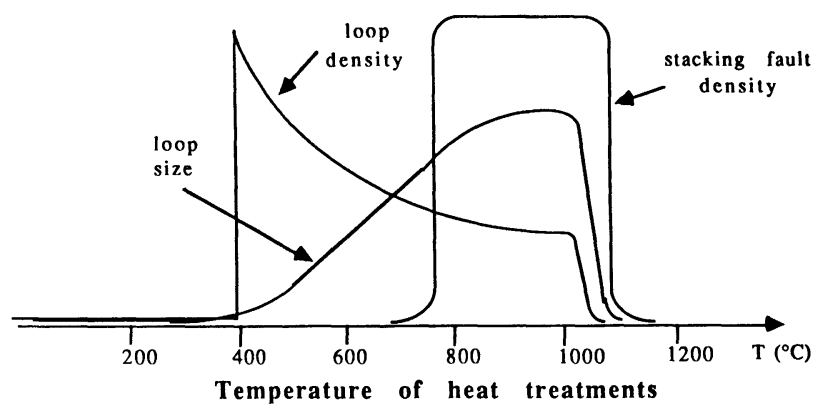

Fig. 4. - Schematic representation of stacking fault, loop densities and loop sizes observed in Te doped GaAs ( $[\mathrm{Te}]>10^{18}$ at. $\mathrm{cm}^{-3}$ ) as a function of the temperature of heat treatments.

no stacking fault have been observed by T.E.M., impurities being in solution;

(ii) annealing at temperatures between $800{ }^{\circ} \mathrm{C}$ and $1000^{\circ} \mathrm{C}$ causes the growth of vacancy loops in $\{111\}$ and $\{110\}$ planes; their size increases with temperature. Isolated stacking faults are also observed. Precipitates sometimes decorate the dislocation loops. The exact characteristics of these defects and the role of other impurities have yet to be worked out in details.

The above mentioned phenomena seem to correspond to the behaviour of GaAs doped with Si [28], Se $[26,27]$ and $S$ [29] as well. On the contrary, $\mathrm{Zn}$ doping gives neither loops nor stacking faults, even at concentrations above $10^{19}$ at.cm ${ }^{-3}$ [26, 27, 29].

In the case of Si doped GaAs [28], annealing at $1100^{\circ} \mathrm{C}$ yields to a homogeneous solid solution. A further annealing at $750^{\circ} \mathrm{C}$ with $[\mathrm{Si}]=4 \times$ $10^{19} \mathrm{at}^{\mathrm{cm}} \mathrm{cm}^{-3}$ causes the formation of a large quantity of small loops, when at 600 and $800{ }^{\circ} \mathrm{C}$, a small number of large loops develops. This anomalous behaviour has been explained by taking into account the formation of $\left(\mathrm{Si}_{\mathrm{Ga}}-\mathrm{V}_{\mathrm{Ga}}\right)$ complexes [28].

Precipitates which have been observed to decorate the above mentioned defects, have been reported, in one case, to be made of arsenic [30]. A detailed study of precipitation in annealed In doped and undoped GaAs [31], has evidenced the following behaviours : (i) at $1000{ }^{\circ} \mathrm{C}$, impurities move back in solution, (ii) at $900{ }^{\circ} \mathrm{C}$, precipitates form on dislocations.

All these observations indicate that annealing in the $800-1000{ }^{\circ} \mathrm{C}$ temperature range is critical for defect formation ; these temperatures probably correspond to those undergone by the growing ingot during the establishment of the dislocation substructure.

\section{Dislocation formation modelling.}

3.1 TemPerAtURE DistribUtion. - A substantial amount of work has been dedicated to find the best conditions for dislocation reduction during growth, using thermal stress modelling (see [32] for review). The models should explain two features: (i) the multiplication of dislocations and their arrangments e.g. in cell boundaries for undoped GaAs, (ii) the influence of doping, with In for instance, which induces a large reduction of dislocation density.

All the models attempt to give a description of the plastic deformation of the crystals due to stresses induced by the thermal gradients, inherent to the growth process. We examine a few examples of the way they manage with the complexity of the problem.

Some authors use finite elements methods which allow a growing boule with its actual cone shape [33, $34]$ to be considered. The analytical solution of the various differential equations can be obtained only for cylindrical crystals [35-38]. In spite of that simplification, many authors use numerical methods [36-38] which give results in agreement with those of analytical ones [36].

The first step of modelling is to calculate the temperature distribution in the growing boule. This requires a correct description of heat exchanges between the crystal and the ambiant medium. The bottom temperature is the melting one $(1511 \mathrm{~K})$ (Fig. 5) and it decreases more or less linearly towards the seed $[10,33,34,36]$ but with different slopes for the part in liquid $\mathrm{B}_{2} \mathrm{O}_{3}$ and the one in argon. Lateral

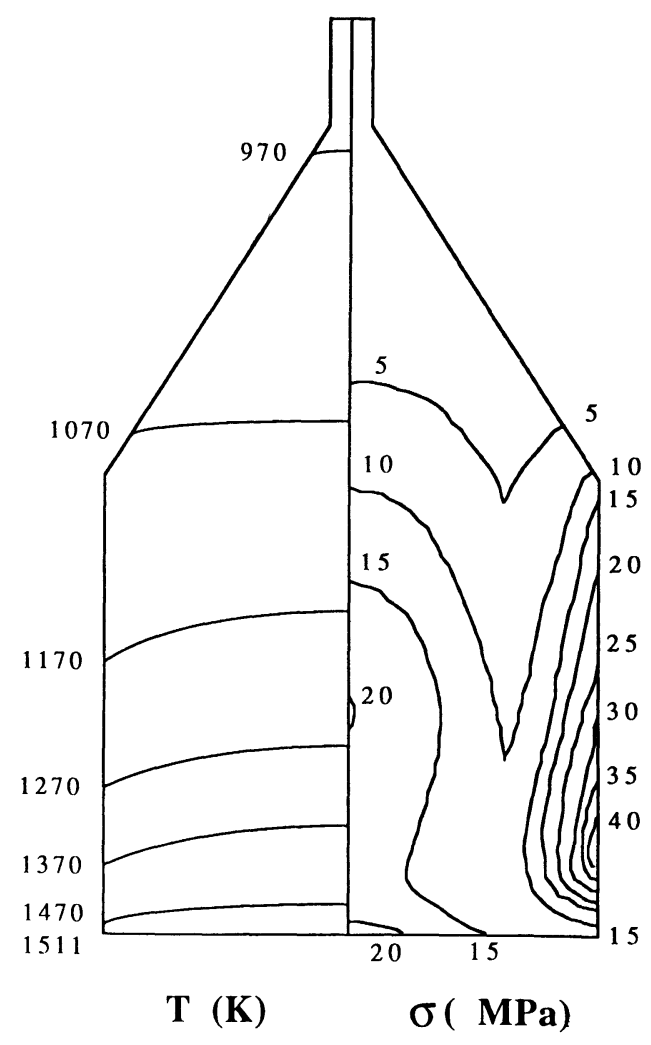

Fig. 5. - Temperatures (left) and stresses (right) distributions in a growing boule (after Duseaux [10]). 
heat exchange is dominated by losses in the ambiant medium, at some distance from the melt. An accurate description of these heat transfers has been made in reference [38] ; the various ways to account for them bring substantially different results.

3.2 Thermal STRESSES. - Thermal gradients result in internal stresses. Suppose that a linearly dependent temperature along the growth axis approximate the situation; in the plane conditions, there is no internal stress. In usual growth conditions the main feature is that the outer part of the boule is cooler than the inner one. This is at the origin of thermal stresses which correspond to a tension of the outer part and a compression of the inner one. This situation retains some similarities with the bending of a beam.

The second step of modelling is to calculate the stress distribution from the temperature distribution. Although this is done by assuming pure elastic behaviour, many approximations are required for the analytical solution to the problem $[35,36]$; numerical techniques [33, 34, 36-38] are not always devoided from artefacts, but they have more widespread use. In any case, the difficulty of the modelling is located at the discontinuity of the liquid-solid interface, which dominates the defect generation. Results show that the stresses are rather independent of the elastic anisotropy ; they strongly depend on the thermal regime related to boule size and heat exchanges $[34,38]$.

The results are presented in various ways by the different authors. The stresses are always found higher in the outer than in the central region, where maximum values of the elastic stresses resolved in a glide plane range from $5 \mathrm{MPa}$ to $20 \mathrm{MPa}[10,33-36]$ (Fig. 5). Meduoye et al. [34] state that there is a good agreement between their results and those of Duseaux [33]. The above mentioned values are larger than those found by Lambropoulos [37] who renders the comparison difficult by an unusual presentation of his results. Motakef et al. [38] make a direct comparison of their numerical solution with the case of the plane strain approximation; the values from the former are three times larger.

All these stress values correspond to parts of the boule where the temperatures are as high as 1100 $1200{ }^{\circ} \mathrm{C}$ (Fig. 5).

3.3 Formation OF DISLOCATIONS. - The next step is to transform these elastic stresses into plastic deformation, a property only recently known for GaAs at high temperature (see Sect. 4). All the quoted authors have used the assumption that the dislocation density $\rho$ is proportional to the difference between the elastic shear stress for the $\langle 110\rangle\{111\}$ slip systems and the corresponding critical resolved shear stress (C.R.S.S.). The difference is retained only when it is positive. Along this way, $\rho$ is calculated by considering one slip plane [36] or twelve slip planes [34, 35, 37, 38]. The first case corresponds to a strong latent hardening which allows only one slip system to operate while the second case assumes no interaction between slip systems. Both descriptions are far from the actual situation in the plastic deformation of GaAs (see Sect. 4) where tests have been conducted at a constant strain rate of $10^{-5}-10^{-4} \mathrm{~s}^{-1}$. When several slip systems are activated, the stress-strain curves are parabolic (Fig. 6) i.e. the C.R.S.S. is not a suitable parameter to describe the deformation. C.R.S.S. values as low as $1 \mathrm{MPa}$ at $800-900{ }^{\circ} \mathrm{C}$ have been used $[34,38]$, which are small compared to the flow stresses after a few percent deformation (Sect. 4). The mechanical parameters deduced from plasticity experiments are obtained in conditions far from those relevant to the situation of crystal growth ; stress and strain rates are not constant with time and their values have not been appreciated. This is one of the limitations concerning the models. The dislocation density should be deduced from a correct account of the mechanics of a boule during growth. It should also include not only dislocation multiplication but also recovery, as revealed by the microstructure (Sect. 2).

In spite of all the limitations of the models, they seem to be able to describe several features of the defect distribution in GaAs single crystals. The four fold or three fold symmetry of dislocation densities is found for $\langle 100\rangle$ and $\langle 111\rangle$ growth axis $[32,35,36$, 39]. Such a result is expected since the crystal symmetry is introduced in the model by the use of the excess stress (elastic resolved shear stress minus C.R.S.S.). The $\mathrm{W}$ shape distribution of dislocations

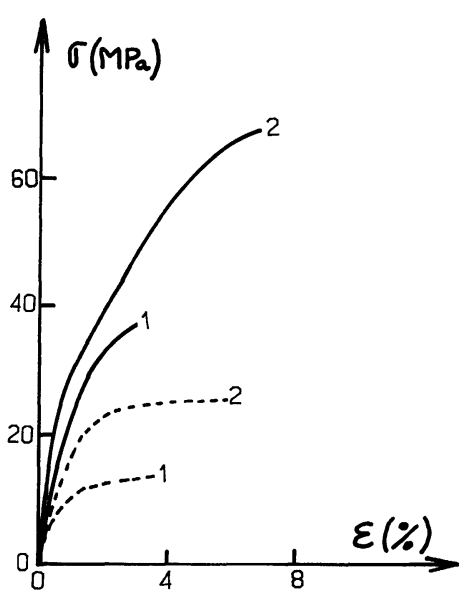

a)

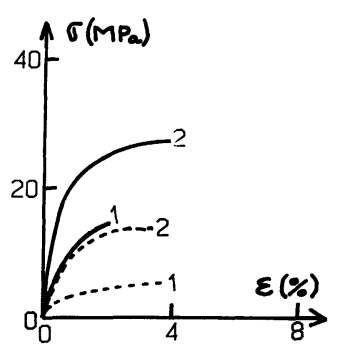

b)
Fig. 6. - Stress-strain curves of undoped (dash line) and In doped $\mathrm{GaAs}$ (solid line), (a) at $900^{\circ} \mathrm{C}$, (b) at $1100^{\circ} \mathrm{C}$. Comparison between the results of Guruswamy et al. [55] (curves 2) and Djemel et al. [53] (curves 1). Different strain rates have been used explaining the discrepency between these results; they are respectively $10^{-4} \mathrm{~s}^{-1}$ and $2 \times 10^{-5} \mathrm{~s}^{-1}$. 
along a radius was found by all the authors. This could be expected when considering the analogy with a bending test. The external part of the crystal is in tension and the inner part in compression. Therefore, there is a region where the stress changes sign and where the dislocation density is minimum. This is about half way between the boule axis and its surface, in agreement with the observations. The models account for the variation of crystal perfection with the growth axis ; $\langle 100\rangle$ grown GaAs is reported to contain more dislocations than $\langle 111\rangle[35,37,40]$.

Obviously, the large interest for modelling stresses during GaAs crystal growth has been stimulated by the necessity to find conditions which minimize dislocation density. The role of impurities has been studied in detail ; it is considered as a proof of the validity of the models. It has been used to calculate the hardening due to In in GaAs [41]. By considering that the dislocation density is essentially zero when the calculated stress is equal to the C.R.S.S., it was concluded that for In doped GaAs the C.R.S.S. is 28 times the one of the undoped crystals, at high temperatures. This is obviously not in agreement with deformation experiments (see Sect. 4). However, it is clear that In hardens GaAs, increasing not only its C.R.S.S. but also its flow stress at various strain levels (Sect. 4); this has an incidence on the way thermal stresses are relaxed during growth, as described by the models $[35,36,39,41]$ and experiments [42].

Recently, there has been an extensive use of models applied to GaAs and InP [32, 35] which both challenge the crystal growers. As far as we know, they do not seem to have been used so extensively to improve the quality of silicon crystals, which are currently pulled without dislocation in diameters over $10 \mathrm{~cm}$. This may be due to good luck with the thermal and mechanical parameters of $\mathrm{Si}$ as compared to those of GaAs. If we assume that GaAs is submitted to a stress level $\sigma=10 \mathrm{MPa}$, it corresponds to a thermal gradient $\Delta T=11 \mathrm{~K}$, by using $\sigma=\alpha E \Delta T \quad(\alpha:$ thermal expansion coefficient, $E$ : elastic Young modulus). Starting with the same $\Delta T$, one find $\sigma=4.5 \mathrm{MPa}$ for silicon, which is a stronger material than GaAs. $\mathrm{Si}$ is stressed at lower levels than GaAs for identical thermal conditions. Actually, there is also another advantage for $\mathrm{Si}$ which has a thermal conductivity three times larger than GaAs, giving smaller temperature gradients. The physical constants for GaAs are such that they render work difficult to reach growth conditions leading to crystals as perfect as silicon.

\section{Mechanical properties : influence of doping.}

\subsection{DEFORMATION.}

4.1.1 Indentation tests. - In spite of the easiness to use it, the indentation test suffers from many draw- backs : unknown and inhomogeneous stress field, poor temperature control... However, a detailed study has been performed by Hirsch et al. [43] with a Vickers indenter on $\{111\}$ planes of GaAs doped with $\mathrm{Te}\left(n \approx 10^{18} \mathrm{~cm}^{-3}\right)$ and $\mathrm{Zn}\left(p \approx 10^{18} \mathrm{~cm}^{-3}\right)$. Tests between $25^{\circ} \mathrm{C}$ and $400{ }^{\circ} \mathrm{C}$ showed that for $\mathrm{n}$ GaAs the Ga $\{111\}$ face is harder than the As $\{111\}$ one. The opposite is found for $p$ type. This was explained by a detailed description of the deformation based on crystallographic slip and dislocation mobilities. Results on In doped GaAs have been reported $[44,45]$, which show an increase of hardness due to doping (Tab. II). However, the results are too scarce to give an account of the variations of GaAs strength with In content and temperature.

Table II. - Hardness measurements in In doped GaAs.

\begin{tabular}{|c|c|c|c|}
\hline $\begin{array}{l}\text { In concen- } \\
\text { tration } \\
\left(\text { at. } \mathrm{cm}^{-3}\right)\end{array}$ & $\begin{array}{c}\text { Tempera- } \\
\text { ture }\end{array}$ & $\begin{array}{l}\text { Hardness } \\
\text { In doped }\end{array}$ & Ref. \\
\hline $2.2 \times 10^{20}$ & $900^{\circ} \mathrm{C}$ & 1.4 & [44] \\
\hline $2.9 \times 10^{20}$ & $\begin{array}{l}500^{\circ} \mathrm{C} \\
700{ }^{\circ} \mathrm{C}\end{array}$ & $\begin{array}{l}2.9 \\
3.2\end{array}$ & [45] \\
\hline
\end{tabular}

4.1.2 Tensile tests. - The tensile test has not been widely used in the case of GaAs. Gorodnichenko et al. [46] have studied p-type ( $\mathrm{Zn}$ doped) and n-type (Sn, Te doped) deformed along $\langle 111\rangle$ at $800^{\circ} \mathrm{C}$ in liquid $\mathrm{B}_{2} \mathrm{O}_{3}$; they find that $\mathrm{n}$ doping hardens (flow stress increasing from $7 \mathrm{MPa}$ for undoped to 12.5 MPa with $[\mathrm{Te}]=10^{18}$ at. $\mathrm{cm}^{-3}$ ) and $\mathrm{p}$ doping slightly softens $\mathrm{GaAs}\left(6 \mathrm{MPa}\right.$ for $\left.[\mathrm{Zn}]=10^{19} \mathrm{at}^{\mathrm{c}} \mathrm{cm}^{-3}\right)$. Similar observations are reported using bending test [47] between $500{ }^{\circ} \mathrm{C}$ and $1000{ }^{\circ} \mathrm{C}$.

Specimens doped with indium (4 to $15 \times 10^{19}$ at. $^{-3}$ ) have been deformed at high temperature in an $\mathrm{X}$ ray topography apparatus [48]. Indium doping hardens $\mathrm{GaAs}$; the stress corresponding to the generation of the first dislocations is insensitive to temperature between $450{ }^{\circ} \mathrm{C}$ and $700{ }^{\circ} \mathrm{C}$, when the upper yield stress decreases with temperature.

4.1.3 Compression tests. - Compression tests have been used in a great number of works between room temperature and $1100{ }^{\circ} \mathrm{C}$ [52-57]. In agreement with the above mentionned results (Sect. 4.1.2), n doping (Te, $\mathrm{Si}$ ) increases the flow stress $\sigma_{\mathrm{f}}$ and $\mathrm{p}$ doping (Zn) slightly decreases it [49-51]. The effect of Te appears above $10^{17}$ at. $\mathrm{cm}^{-3}$ and saturates above 
$10^{19} \mathrm{at}^{\mathrm{cm}} \mathrm{cm}^{-3}$. $\mathrm{Zn}$ has little or no influence on $\sigma_{\mathrm{f}}$, even for concentrations higher than $10^{19}$ at. $\mathrm{cm}^{-3}$.

Isoelectronic doping with indium has been found to increase $\sigma_{\mathrm{f}}$ values between $450{ }^{\circ} \mathrm{C}$ and $1100{ }^{\circ} \mathrm{C}$ [52-55], for tests performed in air, argon and liquid $\mathrm{B}_{2} \mathrm{O}_{3}$. The experimental conditions used by various authors are depicted in table III. A few stress-strain curves are shown in figure 6 for compression tests along the $\langle 100\rangle$ axis of undoped and In doped GaAs, at $900{ }^{\circ} \mathrm{C}$ and $1100{ }^{\circ} \mathrm{C}$; the hardening due to indium is clear for the whole $\sigma-\varepsilon$ curves (Fig. 6). The curves display a parabolic shape, which means that the initial strain hardening $\theta=\mathrm{d} \sigma / \mathrm{d} \varepsilon$ is strong, even at such temperatures (Fig. 6a). This effect is typical of tests along $\langle 100\rangle$; it is much reduced along $\langle 123\rangle$. It is a consequence of multiple slip at the beginning of plastic flow. This makes difficult the determination of the C.R.S.S. from the yield point ; therefore, the flow stress at $0.2 \%$ strain $\sigma_{0.2}$ is used $[52,53]$ which gives results higher than those deduced from $\langle 123\rangle$ compression tests $[54,55]$.

Values for $\sigma_{0.2}$ at various temperatures are displayed in figure 7 for undoped and In doped GaAs.

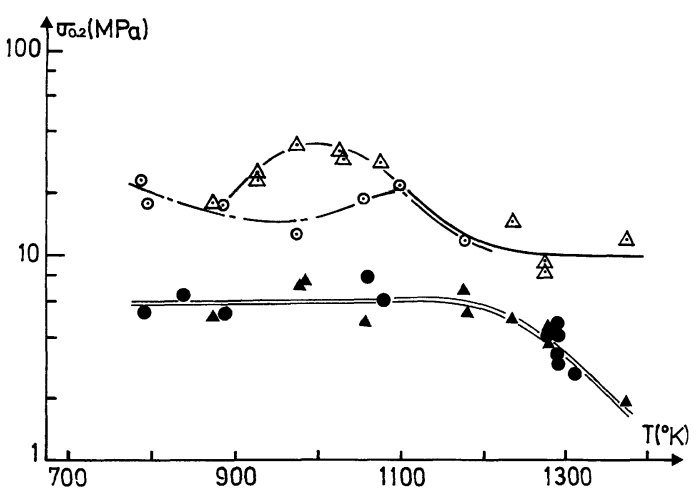

Fig. 7. - Conventional flow stress at $0.2 \%$ strain as a function of temperature for undoped (full symbols) Thomson L.E.P., or doped GaAs (open symbols) [In] = $5 \times 10^{19}$ at.cm ${ }^{-3},[$ In $]=(1-4) \times 10^{20}$ at.cm ${ }^{-3}$.
Besides the hardening due to indium, one can notice that $\sigma_{0.2}$ has maximum values which depend on the indium content. This behaviour has been attributed to dynamic strain ageing (Portevin Le Chatelier effect), attested by the serrated yielding observed in constant strain rate compression [53].

The hardening effects of dopants is summarized in figure 8 , by plotting the ratio of yield stresses for doped and undoped $\mathrm{GaAs}$; this plot has been drawn at the temperatures $500{ }^{\circ} \mathrm{C}$ and $800{ }^{\circ} \mathrm{C}$ where the measurements are numerous. Isoelectronic and $\mathrm{n}$ doping are very effective in hardening GaAs, at variance with $\mathrm{Zn}$ p type doping.

\subsection{DISLOCATION SUBSTRUCTURE AFTER DEFOR- MATION.}

4.2.1 General features. - After deformation at $500{ }^{\circ} \mathrm{C}$, of undoped GaAs, T.E.M. examination

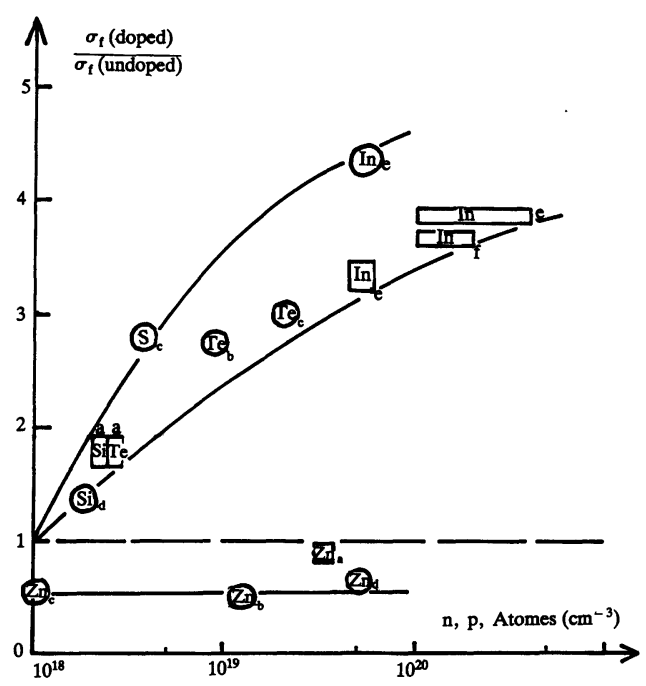

Fig. 8. - Summary of the effects of electrical and isoelectronic doping on the ratio of the flow stresses for undoped and doped GaAs. $500^{\circ} \mathrm{C}, 800{ }^{\circ} \mathrm{C}$. (a) Gorodnichenko et al. [46], (b) Sazhin et al. [49], (c) Osvenskii et al. [50], (d) Swaminathan et al. [51], (e) Djemel et al. [53], (f) Guruswamy et al. [55].

Table III. - Experimental conditions of the compression tests.

\begin{tabular}{|c|c|c|c|c|c|}
\hline $\begin{array}{c}\text { Indium } \\
\text { concentration } \\
\left(\text { at. } \mathrm{cm}^{-3}\right)\end{array}$ & $\begin{array}{c}\text { Temperature } \\
\text { range }\end{array}$ & $\begin{array}{c}\dot{\varepsilon} \\
\mathrm{s}^{-1}\end{array}$ & Environment & $\begin{array}{c}\text { Compres. } \\
\text { direction }\end{array}$ & Ref. \\
\hline $\begin{array}{c}\text { undoped } \\
5 \times 10^{19} 1-4 \times 10^{20}\end{array}$ & $400-1100^{\circ} \mathrm{C}$ & $1.4-1.7 \times 10^{-5}$ & $\begin{array}{c}\text { Air, Ar, } \\
\text { liq } \mathrm{B}_{2} \mathrm{O}_{3}\end{array}$ & $\langle 100\rangle$ \\
\hline $\begin{array}{c}\text { undoped } \\
2.9 \times 10^{19}\end{array}$ & $350-1100^{\circ} \mathrm{C}$ & $10^{-4}$ & $\begin{array}{c}\mathrm{Ar}, \\
\text { liq } \mathrm{B}_{2} \mathrm{O}_{3}\end{array}$ & $\langle 123\rangle$ & {$[53]$} \\
\hline $1-2 \times 10^{20}$ & $700-1100^{\circ} \mathrm{C}$ & $10^{-4}$ & $\begin{array}{c}\mathrm{Ar}, \\
\text { liq } \mathrm{B}_{2} \mathrm{O}_{3}\end{array}$ & $\begin{array}{l}\langle 123\rangle \\
\langle 100\rangle\end{array}$ & {$[55]$} \\
\hline
\end{tabular}


revealed a rough polygonization for $8 \%$ strain, with cell sizes of about $10 \mu \mathrm{m}$ [58] ; this phenomenon is similar to the one observed in f.c.c. metals at intermediate temperatures [15]. The same observation was made in $\mathrm{Zn}$ doped GaAs [59], but not in Si doped GaAs where long segments of screw or $60^{\circ}$ dislocations are associated with the deformation. At higher temperature the polygonization is more regular, with thin walls between cells.

For In doped GaAs, the cell structure develops with sizes of the order of $1 \mu \mathrm{m}$ [58] ; the reduction of the distance between subgrain-boundaries in In doped GaAs with respect to undoped GaAs is expected as a consequence of the larger flow stress (Figs. 6 and 7). The polygonization substructure appears at higher temperature for higher indium concentration [60].

4.2.2 Dislocation dissociation. - Dissociation of dislocations in GaAs can be observed by T.E.M. using the weak beam technique. For undoped crystals, the distance between partials is 5 to $6 \mathrm{~nm}$, identical for $\alpha$ and $\beta$ dislocations observed in equal number ; it corresponds to a stacking fault energy (S.F.E.) of $45 \mathrm{~mJ} . \mathrm{m}^{-2}$ [58, 61-65]. A decrease in S.F.E. has been mentionned by Astakhov et al. [66] for $\mathrm{Te}$ and $\mathrm{Sn}$ doped, $\mathrm{n}$ type GaAs ; they made a deduction from T.E.M. observations of microtwins. On the contrary, no change in S.F.E. was found in deformed GaAs doped with $\mathrm{Si}\left(n \approx 4.10^{17} \mathrm{~cm}^{-3}\right)$, $\mathrm{Zn}\left(p \approx 2.10^{18} \mathrm{~cm}^{-3}\right)$ and $\mathrm{Cr}\left(\approx 10^{17}\right.$ at. $\left.\mathrm{cm}^{-3}\right)[65]$; these concentrations happen to be below the threshold of figure 2. High resolution T.E.M. examination of a $60^{\circ}$ dislocations, in heavily Te doped $\mathrm{GaAs}$, does not seem to reveal any change in S.F.E. [67] although the published micrograph corresponds to a S.F.E. of $36 \mathrm{~mJ} . \mathrm{m}^{-2}$, slightly smaller than the one for undoped GaAs. An even larger decrease in S.F.E. has been observed in GaAs containing 1 to $4 \times 10^{20}$ at. $\mathrm{cm}^{-3}$ of In deformed between 650 and $1000{ }^{\circ} \mathrm{C}$ [60]; with a separation between partials of $9 \pm 1 \mathrm{~nm}$, the S.F.E. is $27 \mathrm{~mJ} \cdot \mathrm{m}^{-2}$. The distance between partials was the same for the various test temperatures [60]. On the contrary, for In doped GaAs with [In] $=5 \times$ $10^{19}$ at. $\mathrm{cm}^{-3}$ deformed at $500{ }^{\circ} \mathrm{C}$, the S.F.E. was unchanged [58].

4.3 Dislocation MOBILITY. - It is usual to determine the dislocation velocities by measuring the displacements of segments, introduced by a scratch, after application of a stress at a fixed temperature. For GaAs, these displacements have been observed either by double etch pitting or by X-ray topography, the stress being applied by bending.

The measurements were performed between 200 and $7500^{\circ} \mathrm{C}$, with difficulties above $600{ }^{\circ} \mathrm{C}$ related to the evaporation of arsenic. We do not consider the recombination enhanced motion of dislocations due to light or electron irradiation [68].

Several studies have been performed, mainly on undoped GaAs ; the results of the various authors are rather scattered because of many uncontrolled parameters (impurity contents, stress levels...). In addition, undoped crystals contain a fairly large amount of grown-in dislocations which may impede the motion of fresh ones and prevent safe comparisons with dislocation-free doped GaAs. However, several results seem to be well established :

(i) two kinds of $60^{\circ}$ dislocations are present in compound semiconductors : $60^{\circ} \alpha$ (As core) and $60^{\circ}$ $\beta$ (Ga core) velocities are very different for identical conditions. At $300{ }^{\circ} \mathrm{C}$ and $\sigma=10 \mathrm{MPa}$, the values found were $v_{\alpha}=10^{-5} \mathrm{~cm} . \mathrm{s}^{-1}$ and $v_{\beta}=10^{-7} \mathrm{~cm} . \mathrm{s}^{-1}$ (Fig. 9). At higher temperatures, the difference tends to disappear ;

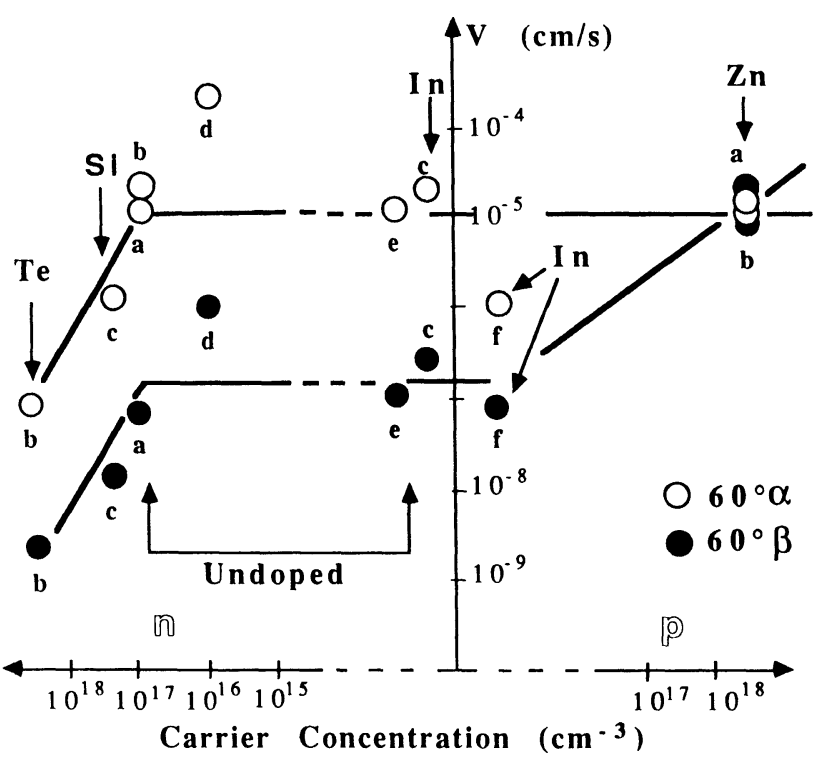

Fig. 9. - Influence of the impurity addition on the velocity of $60^{\circ} \alpha$ and $\beta$ dislocation at $300^{\circ} \mathrm{C}$ and $10 \mathrm{MPa}$, (a) Choi et al. [69], (b) Steinhart et al. [72], (c) Extrapolation from Yonenaga et al. [74], (d) Osvenskii et al. [71], (e) Erofeeva et al. [70], (f) Burle-Durbec et al. [73].

(ii) in the $200-600{ }^{\circ} \mathrm{C}$ range, dislocation segments are aligned with the Peierls valleys and the velocity follows an Arrhenius law. Except for p-doped GaAs, the activation energies of $\alpha$ and $\beta$ dislocations are the following:

$0.9 \mathrm{eV}<E_{\alpha}<1.2 \mathrm{eV}$ and $1.25 \mathrm{eV}<E_{\beta}<1.6 \mathrm{eV}$;

(iii) for n-type undoped GaAs, dislocation velocities are independent of carrier concentrations (Fig. 9) [69-71] ;

(iv) electrically active dopants have a complex influence on dislocation mobilities, which is summarized in figure 9 . We show only results for $60^{\circ}$ 
$\alpha$ and $\beta$. For both core configurations, dislocation velocities are substantially lowered for dopants giving a n-type, as shown by results with $\mathrm{Te}$ and $\mathrm{Si}$ (Fig. 9) [69-72]. Conversely, p-type obtained with $\mathrm{Zn}$ leaves $\alpha$ velocities unchanged and increases the $\beta$ ones to the level of $\alpha$ dislocations (Fig. 9) [69, 72] ;

(v) with isoelectronic doping by indium, $\beta$ velocities are identical to those of undoped GaAs (Fig. 10) when that of $\alpha$ dislocations is reduced [73, 74]. A more specific property has been observed on $60^{\circ}$ $\alpha$ and screw dislocations above $400{ }^{\circ} \mathrm{C}[73,74]$; the stress velocity curves display a discontinuity at low stress (below $8 \mathrm{MPa}$ ) (Fig. 10). The height of the step at $8 \mathrm{MPa}$ depends on the duration of the specimen annealing during the experiment. Actually, in these conditions, dislocations behave in an irregular manner and the average velocities which are measured, turn to be unsafe. This is due to dynamic interactions between impurities and dislocations, leading to lockings $[73,74]$; such interactions have been already pointed out at higher temperatures in mechanical tests (see 4.1.3) [53]. The dislocation lockings are only observed for $60^{\circ} \alpha$ and screw dislocations; this can be attributed to a specific interaction between indium and $\alpha$ partials which are common to both types of dislocations [74-76].

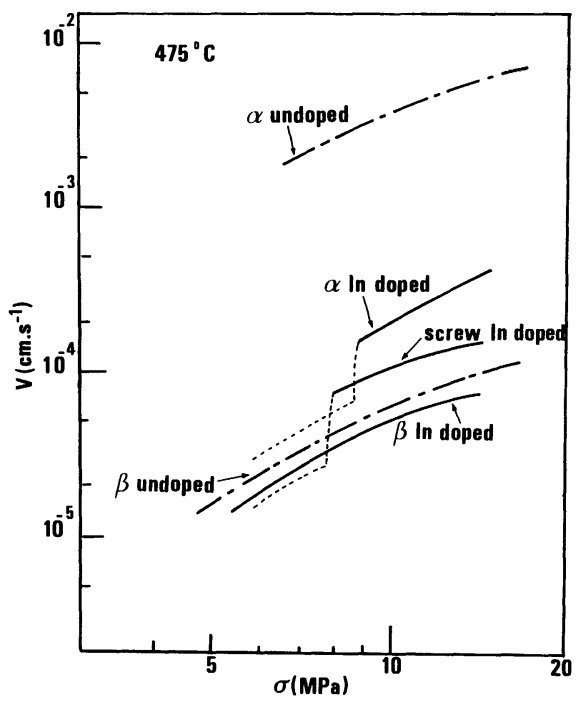

Fig. 10. - Dislocation velocities vs. resolved shear stress in undoped and In doped GaAs at $475^{\circ} \mathrm{C}$.

Dislocation velocities in GaAs have been measured by other techniques. In situ experiments at $350{ }^{\circ} \mathrm{C}$ in a T.E.M. [77] showed that, like in $\mathrm{Si}$ and $\mathrm{Ge}$, the velocities of dislocations depend on the length $\ell$ of the observed segments for $\ell<1.3 \mu \mathrm{m}$; above this value, there is no influence of $\ell$ values. Dislocation rosettes around indentations show variable extensions, explained by the difference in $60^{\circ}$ $\alpha$ et $\beta$ mobilities [56, 78].

\section{Discussion.}

5.1 ORIGIN OF THE SUBSTRUCTURE IN AS-GROWN GaAs. - As already mentionned, the substructure in undoped GaAs, just after L.E.C. growth, is reminiscent of the one observed in metals after deformation at medium temperature, where the flow stress $\sigma_{\mathrm{f}}$ is athermal [15].

T.E.M. examinations have shown that dislocations first pile-up on Lomer-Cottrell locks, then cross-slip to avoid these obstacles ; they end in heterogeneous distributions described as cell structures. Such features are observed in as-grown GaAs ; they correspond to the ultimate deformation conditions undergone by the crystals during growth. These mechanisms correspond to a temperature range $700-1000{ }^{\circ} \mathrm{C}$ $\left(0.64 T_{\mathrm{M}^{-}} 0.84 T_{\mathrm{M}}\right)$ where cross-slip is more efficient than climb to move dislocations out of their glide plane. The latter mechanism is clearly active to generate helical dislocations (see Sect. 2.2.1), point defect supersaturation helping such a process. No other evidence of climb has been reported.

Direct observations of the substructure give some hints on the last steps of its establishment. In order to understand the mechanism of dislocation density reduction by doping, we have to be able to describe the importance of the following steps :

(i) dislocation sources must first be activated by thermal stresses. Before that, they must be formed, which generally occurs by point defect condensation [79]. Then, long enough segments must be present or forced in glide planes ;

(ii) dislocations emitted by these sources must glide across long enough distances before they meet obstacles, due to dislocations from other glide planes ;

(iii) overcoming these obstacles then occurs by cross-slip, filling the crystals with dislocation tangles.

We now discuss, on the basis of mechanical tests and the processes they involve, if the plastic deformation during growth is able to explain all the features of dislocation formation in undoped and doped GaAs.

5.2 Plastic Deformation. - Plastic deformation of $\mathrm{GaAs}$ has been evaluated both by macroscopic and microscopic studies which give coherent results in their common temperature range. Indeed, doping which decreases dislocation velocities, increases the flow stress of bulk single crystals and is correlated with a reduction of as-grown dislocation density. This suggests, that in spite of the diversity of deformation conditions, the same mechanisms control the dislocation glide and multiplication. At least below $700{ }^{\circ} \mathrm{C}$ the model of Alexander and Haasen [80] gives an adequate description of the relation between dislocation velocity $v$ and macroscopic flow stress $\sigma$. Starting from the equation : 


$$
v=v_{0}\left(\frac{\sigma_{\text {eff }}}{\sigma_{0}}\right)^{m} \exp (-Q / k T)
$$

$\sigma_{\text {eff }}$ : effective stress i.e. applied stress $\sigma$ minus backstress due to dislocations. $m$ and $Q$ (activation energy) are parameters typical of dislocation-obstacle interactions (Peierls forces, impurities, dislocations...).

It gives for the lower yield stress $\sigma_{\text {ly }}$ :

$$
\sigma_{\mathrm{ly}}=C(\dot{\varepsilon})^{1 / m+2} \exp [Q /(m+2) k T]
$$

$C$ : constant, $\dot{\varepsilon}$ : strain rate.

There is a good fit between experimental values of $m$ and $Q$ determined from velocity and yield stress measurements [54, 72, 81].

For indium doped $\mathrm{GaAs}$, the complexity of the behaviour at the level of individual screw and $60^{\circ}$ $\alpha$ dislocations (Fig. 10) interpreted in terms of interactions with impurities $[75,76]$ is obviously related to the static strain ageing observed in constant strain rate compression at $600-700{ }^{\circ} \mathrm{C}$ [53]. Dislocation behaviour and mechanical data have been simultaneously observed in In doped GaAs, by in-situ deformation in a X-ray topography equipment [48] (see Sect. 4.1.2). In In doped GaAs the distribution of dislocations is more heterogeneous; sources are less numerous than in undoped crystals. This suggests a strong confinement of dislocations in their glide plane. This also explains that the polygonization substructure appears at higher temperature in doped crystals than in undoped [60]. A common explanation is that cross-slip and/or climb are rendered more difficult by the presence of large amounts of indium. Indeed this is supported by the large difference in stage III flow stress $\sigma_{\text {III }}$ (steady state deformation at constant stress) for the two types of GaAs (Fig. 6) [52]. Larger $\sigma_{\text {III }}$ are necessary to induce cross-slip events in doped materials than in undoped. The impediment to these events is also traced in the features of grown-in dislocations (Fig. 3, see Sect. 2.2.1).

Deformations along a $\langle 100\rangle$ axis activate several glide planes with a consequence that the specimens harden with strain (Fig. 6) [51-53, 55]; at small strains, Lomer-Cottrell locks are formed which are strong obstacles to dislocation glide. This is the major step in the formation of the microstucture. The crystallographic conditions during growth are close to those of $\langle 100\rangle$ tests, similar microstructural features being formed in both cases. It is, therefore, difficult to extract from plastic deformation experiments, a parameter which is suitable for the thermoelastic models of dislocation generation (see Sect. 3). The microscopic approach seems more suitable to understand the underlying mechanisms for dislocation generation during growth.

5.3 ObStACles to Dislocation MOtion. - A foreign atom in a matrix may have various types of interactions with a dislocation. Three of them are most often considered, which are relevant to GaAs : electric interaction, bonding energy effects (elastic modulus) and elastic interactions between stress fields of defects. In addition to these effects, we discuss the influence of impurities on stacking fault energies, which may directly influence dislocation multiplication. In the whole discussion, we have to keep in mind that the mechanisms we are interested in, must be effective at temperatures as high as 900$1000^{\circ} \mathrm{C}$ in GaAs.

5.3.1 Electrical effects. - Ionized impurities generally form neutral complexes, which may be split by dislocations, thus increasing their electrostatic energy. This idea was introduced by Gilman [82] to explain the impurity hardening of alkali halides. It was used by Swaminathan et al. [83] to explain the hardening of $\mathrm{GaAs}$ by $\mathrm{Si}$, due to the presence of $\left(\mathrm{Si}_{\mathrm{Ga}}-\mathrm{V}_{\mathrm{Ga}}\right)$ complexes. This provided a useful explanation for hardening below $750{ }^{\circ} \mathrm{C}$, the complexes dissolving above this temperature [83]. Dislocation density reduction during growth cannot be explained by such a mechanism.

In addition an evaluation of such a mechanism has been made by Mitchell et al. [84] ; they conclude that, for alkali halides, $\mathrm{MgO}$ and $\mathrm{Al}_{2} \mathrm{O}_{3}$, the elastic interaction is dominant with respect to the above mentioned electrical effect.

Electrical effects may directly influence the dislocation glide when it is controlled by the nucleation and propagation of kink pairs (Peierls mechanism). These may be influenced by the $\mathrm{p}$ and $\mathrm{n}$ doping, which can affect $60^{\circ} \alpha, \beta$ and screws in different ways, allowing to understand the experiments (see Sect. 4.3). There are two kinds of explanations (see [1] for review) :

(i) kink formation energies depend on the charge of the dislocation, which is related to the position of its energy level with respect to the Fermi energy $E_{\mathrm{F}}$;

(ii) kinks on dislocations are associated to energy levels in the band gap. Their number is then directly related to $E_{\mathrm{F}}$. These assumption seems well suited to describe the properties of dislocations in GaAs at low temperature, below $600{ }^{\circ} \mathrm{C}$. Above $600{ }^{\circ} \mathrm{C}$, the various types of dislocations behave in a very similar way. Electrical impurities could still operate, in the assumption of a Peierls mechanism; it is only above $1200{ }^{\circ} \mathrm{C}$ [85] that thermal carrier concentration exceeds that of dopants $\left(10^{17}-10^{18} \mathrm{~cm}^{-3}\right)$, thus eliminating their influence. Electric interactions could provide an explanation for high temperature hardening in a limited number of cases.

5.3.2 Bonding energy effects. - It is assumed that, in solid solution hardening in covalent crystal, the bonding energy (or its derivative) of the dopant $\mathrm{X}$ 
with $\mathrm{Ga}$ or As atoms may be an obstacle to dislocation movements. Seki et al. [7] have used this assumption to explain the effect of doping on dislocation densities. The parameter to evaluate the efficiency of the obstacle is related to the magnitude of the difference in bonding energies: $\Delta E=$ $E_{\mathrm{GaX}}-E_{\mathrm{GaAs}}$ or $\Delta E=E_{\mathrm{XAs}}-E_{\mathrm{GaAs}}$. Values of these energies are summarized in table I. It can be noticed that isoelectronic impurities of column $\mathrm{V}$ and donors of column VI fit in the suggested model. However, there are many exceptions, e.g. Zn which has no influence on dislocations despite a large $\Delta E$ value. This assumption seems too simple to give a general frame to explain the hardening effect of dopants. However, it has been used in relation to the various types of dislocation cores which exist in compound semiconductors [86]. A peculiar interaction between indium and one of the partials is able to account for the differences in mobilities of $60^{\circ} \alpha$, screw and $60^{\circ}$ $\beta$ dislocations $[75,76]$. This provides an explanation for $\mathrm{GaAs}$ hardening at moderate temperatures.

5.3.3 Elastic interaction: size effect. - The size effect is usually considered as the origin of solid solution hardening in metals. Its magnitude is estimated by taking a local deformation $\delta R=\left(R-R_{0}\right) / R_{0}$ where $R$ is the radius of the impurity and $R_{0}$ the radius of the matrix atom which is substituted. Various data for $\delta R$ are presented in table I. This deformation is not very large for dopants fairly efficient like $\mathrm{Se}, \mathrm{S}, \mathrm{Te}, \mathrm{Si}$; in addition, the concentration levels $\left(10^{18} \mathrm{at} . \mathrm{cm}^{-3}\right)$ are much lower than those considered in metals. It is doubtful that such effect can be used to explain the impurity hardening of $\mathrm{GaAs}$.

For isoelectronic dopants, the $\delta R$ values are fairly large and this yield to an efficient locking of dislocations [87]. A detailed calculation of the elastic interaction energy $W$ between a dislocation and an In atom situated at a distance $r$, can be done, based on the equation [88] :

$$
W=W_{m}\left(\frac{b}{r}\right)^{n} f(\Phi)
$$

$W_{m}$ is the energy corresponding to $r=b$ the Burgers vector $f(\Phi)$ describes the angular dependence of the interaction. For a size effect, $n=1$ and for a modulus effect $n=2$. A value of $n=1$ was found experimentally [53].

Erhenreich et al. [89] have made a detailed calculation, where they assumed that $\operatorname{InAs}_{4}$ is the hardening entity; the In-As distance where taken from E.X.A.F.S. measurements. They explained the reduction of grown-in dislocation density by this mechanism [89], although its best applicability is for high impurity concentration and low temperatures.

The size effect may contribute, in some cases, to the improvement of GaAs perfection by iso-elec- tronic doping; however, $\mathrm{Al}$ is effective in spite of $\varepsilon=0$ (Tab. I). The bonding energy effect (see Sect. 5.3.2) could be responsible for that. The situation for boron $(\varepsilon=30 \%)$ needs to be clarified [10].

Indirect effects related to the size of impurities can be invoked to explain the reduction of dislocation densities. This could occur via the free vacancies, which in usual growth conditions, are largely in supersaturation. Indium, which has a large radius, could trap a large number of vacancies, decreasing their supersaturation and preventing them from condensing in dislocation loops. This would decrease the source density, preventing the spread of dislocations in the growing crystals.

5.3.4 Stacking fault energy. - Dopants may alter the dissociation of dislocations. It is a common observation in metals and alloys [90]. There are only limited observations in semiconductors; Sato et al. [91] have shown that the addition of phosphorus in silicon decreases the dissociation of dislocations after deformation. An effect on dissociation width may arise from a change either in the interaction between partial dislocations or in the stacking fault energy ;

(i) one can expect a repulsive interaction between partials, which depends on their electrical charge. This requires that the screening distance $\lambda$ is larger than the separation between partials [92]:

$$
\lambda^{2}=\frac{k T \chi}{4 \pi e^{2} n}
$$

$\chi$ : dielectric constant, $e$ : electron charge, $k:$ Boltzmann constant.

For $n=10^{18} \mathrm{~cm}^{-3}, T=1000^{\circ} \mathrm{C}$, one finds for GaAs $\lambda=2 \mathrm{~nm}$, which is smaller than the dissociation width (see Sect. 4.2.2). There is no electrical interaction between partials ;

(ii) foreign atoms can segregate on the stacking fault ribbon (Suzuki effect), the S.F.E. value decreasing with the presence of impurities. The effect is particularly efficient at high temperature. This provides an explanation for the increase of dissociation width observed in Te doped GaAs [66, 67] and in In doped [60], as well as for the large stacking faults in n-type GaAs, as grown and after annealing [23]. In all these instances, impurities would have segregated in the stacking faults.

This observation suggests a very attractive explanation for a whole set of experimental facts in high temperature dislocation behaviour in GaAs. Crossslip is inhibited by large dissociation, which explains the strength of In doped GaAs in stage III and its reluctance to form a substructure (see Sect. 5.2). The same mechanism would prevent In doped GaAs to be filled with dislocations during the L.E.C. growth. The threshold concentration (Fig. 3) is not 
unusual as such a threshold has been observed in f.c.c. metals in connection to a decrease in stacking fault energies [90].

For electrically active dopants ( $\mathrm{Si}$ ), the observations did not show an increase in the dissociation width of dislocations [65]. However, the concentration was below the threshold, which does not allow to conclude. Results for Te doping [66, 67] seem to support our explanation.

\section{Conclusions and summary.}

The aim of the paper was to clarify the mechanisms involved in the substructure formation during the L.E.C. growth of GaAs and its elimination by doping. Many explanations are still possible; the following can be put forward :

(i) the substructure forms by a sequence of events : activation of dislocation sources ; LomerCottrell locks formation ; cross-slip, which all happen between 700 and $1000{ }^{\circ} \mathrm{C}$ under the action of thermoelastic stresses ;

(ii) deformation experiments and dislocation velocity measurements are in agreement, in their common temperature range, the former being also performed at very high temperature. $\mathrm{N}$ doping hardens $\mathrm{GaAs}$ and decreases velocities; p-doping slightly softens $\mathrm{GaAs}$ and increases the velocity of $60^{\circ} \beta$ dislocations. Indium doping gives rise to dynamic interactions with dislocations observed both in deformation experiments and velocity measurements ;

(iii) the dopants are more effective to prevent dislocation propagation out of their glide plane than to eliminate sources ;

(iv) in the Peierls domain the effect of $n$ or $p$ type doping is electronic ;

(v) hardening by indium is a combination of size effect and Suzuki effect.

More work is necessary to firmly establish the various assumptions. It would be interesting to make more T.E.M. observation to relate the width of dissociation with the concentration of dopants ( $\mathrm{Si}$, Te...) in particular around the threshold concentration.

\section{Acknowledgments.}

The authors wish to thank Pr. A. Zaoui, Dr. T. Bretheau (LPMTM University Paris XIII, France) and Pr. F. Minari (University Aix-Marseille III, France) for helpfull discussions.

\section{References}

[1] George A. and Rabier, J. Revue Phys. Appl. 22 (1987) 941.

[2] Miyazawa S., Mizutani T. and Yamazaki H., Jpn J. Appl. Phys. 21 (1982) L542.

[3] Shimada T., Terashima K., NaKajima H. and Fukuda T., Jpn J. Appl. Phys. (1983) L23.

[4] Duseaux M., Schiller C., Cornier J. P., Chevalier J. P. and Hallais J., J. Phys. Colloq. France 44 (1983) C4-397.

[5] Gault W. A., Monberg E. M. and Clemans J. E., J. Cryst. Growth 74 (1986) 491.

[6] Abernathy C. R., Kinsella A. P., Jordan A. S., Caruso R., Pearton S. J., Temkin H. and WADE H., J. Cryst. Growth 85 (1987) 106.

[7] Seki Y., Watanabe H. and Matsui J., J. Appl. Phys. 49 (1978) 822.

[8] Jacob G., Farges J. P., Schemali C., Duseaux M., Hallais J., Bartels W. J. and RoKSNOER P. J., J. Cryst. Growth 57 (1982) 245.

[9] Elliot A. G., Wei C. L., Farraro R., Woolhouse G., SCOTT H. and HisKes R., $J$. Cryst. Growth 61 (1983) 417.

[10] DuseauX M., Thesis, University of Paris VI (1982).

[11] MIL'VIDSKII M. G., OsVENSKII V. B. and SHIFRIN S. S., J. Cryst. Growth 52 (1981) 396.

[12] Hiray ama M., Togashi M., Kato N., Suzuki M., MATSUOKA Y. and KAWASAKI Y., IEEE Trans. Electron Devices ED-33 (1986) 104.
[13] Muller G., Rupp L., VölKl H. and Blum W., J. Cryst. Growth 71 (1985) 771.

[14] Defect Recognition and Image Processing in III-V comp. 2, Ed. E. R. Weber (Elsevier) Mat. Sci. Monographs 44 (1987).

[15] VeYssière P., Ecole d'été, Dislocations et déformation Plastique, Yravals (Les Editions de Physique) 1979.

[16] Ono H. and Matsui J., Appl. Phys. Lett. 51 (1987) 801 ; J. Cryst. Growth 89 (1988) 209.

[17] Lagowski J., Gatos H. C., Aoyama T. and LiN D. G., Appl. Phys. Lett. 34 (1984) 680.

[18] Pichaud B., Burle-Durbec, N. and Minari F., Defect Recognition and image Processing in IIIV Compounds 2, Ed. E. R. Weber (Elsevier) Mat. Sci. Monographs 44 (1987) 109.

[19] Carruthers J. R. and WitT A. F., Crystal Growth and Characterization, Eds. R. Ueda and J. B. Mullins (North-Holland, Amsterdam) 1975.

[20] MAtsui J., Microscopy of Semiconducting Materials 1987, Eds. A. G. Cullis and P. D. Augustus, Inst. Phys. Conf. Ser. 87 (1987) 269.

[21] Scott M. P., Laderman S. S. and Elliot A. G., Appl. Phys. Lett. 47 (1985) 1280.

[22] Burle-Durbec N., Pichaud B., Minari F., Soyer A. and Epelboin Y., J. Appl. Cryst. 19 (1986) 140.

[23] Laister D. and Jenkins G. M., J. Mater. Sci. 3 (1968) 584. 
[24] Laister D. and Jenkins G. M., Philos. Mag. 16 (1971) 1077.

[25] Cornier J. P., Duseaux M., Chevalier J. P., Inst. Phys. Conf. Ser. 74 (1985) 9.

[26] Hutchinson P. W. and Dobson P. S., Philos. Mag. 30 (1974) 65.

[27] Hutchinson P. W. and Dobson P. S., J. Mater. Sci. 10 (1975) 1636.

[28] Narayanan G. H. and Kachare A. H., Phys. Status Solidi (a) 26 (1974) 657.

[29] Kamejima T., Matsui J., Seki Y. and Watanabe H., J. appl. Phys. 50 (1979) 3312.

[30] Cullis A. G., Augustus P. D. and Stirland D. J., J. Appl. Phys. 51 (1980) 2556.

[31] Suchet P., Thesis, Institut Polytechnique de Lorraine, Nancy (1987).

[32] Jordan A. S., Von Neida, A. R., Caruso R., J. Cryst. Growth 76 (1986) 243.

[33] Duseaux M., J. Cryst. Growth 61 (1983) 576.

[34] Meduoye G. O., Bacon D. J., Evans K. E., J. Cryst. Growth 88 (1988) 397.

[35] JoRdan A. S., J. Cryst. Growth 71 (1985) 559.

[36] SchVezov C., Samarasekera I. V., Weinberg F., J. Cryst. Growth 84 (1987) 212 (I) and 219 (II).

[37] Lambropoulos J. C., J. Cryst. Growth 84 (1987) 349.

[38] Motakef S., De Witt A. F., J. Cryst. Growth 80 (1987) $37 ; 88$ (1988) 341.

[39] Jordan A. S., J. Cryst. Growth 49 (1980) 631.

[40] Fornari R., PAORICI C., ZANOTTI L., ZeCChina L., J. Cryst. Growth 84 (1987) 266.

[41] McGuigan S., Thomas R. N., Barret D. L., Hobgood H. M., Swanson B. W., Appl. Phys. Lett. 48 (1988) 1377.

[42] Elliot A. G., Wei C. L., Vanderwater D. A., $J$. Cryst. Growth 85 (1987) 59.

[43] Hirsch P. B., Pirouz P., Roberts S. G. and WARren P. D., Philos. Mag. B 52 (1985) 759.

[44] Guruswamy S., Hirth J. P. and FABER K. T., J. Appl. Phys. 60 (1986) 4136.

[45] Bourret E. D., Tabache M. G., Beeman J. W., Elliot, A. G. and ScOtT M. P., J. Cryst. Growth 85 (1987) 275.

[46] GoRodNICHENKo O. K., GlushKov E. A., Kovalenko V. F. and VAsilenko N. D., Phys. Status Solidi (a) 79 (1983) 331.

[47] Laister D. and Jenkins G. M., J. Mater. Sci. 8 (1973) 1218.

[48] Tohno S., Shinoyama S. and Katsui A., Appl. Phys. Lett. 49 (1986) 1204.

[49] SAZhin N. P., MiL'vidskiI M. G., Osvenski V. B. and Stolyarov O. G., Sov. Phys.-Solid State 8 (1966) 1223.

[50] OsvenskiI V. B., Stolyarov O. G., Milvid'skiI M. G., Sov. Phys.-Solid State 10 (1969) 2540.

[51] Swaminathan V. and Copley S. M. J. Am. Ceram. Soc. 58 (1975) 482.

[52] DJEMEL A. and CASTAING J., Europhys. Lett. 2 (1986) 611.

[53] Djemel A., Castaing J. and Duseaux M., Philos. Mag. A 57 (1988) 671.

[54] Tabache M. G., Bourret E. D. and Elliot A. G., Appl. Phys. Lett. 49 (1986) 289.
[55] Guruswamy S., RaI R. S., FABER K. T. and HirTh J. P., J. Appl. Phys. 62 (1987) 4130.

[56] Androussi Y., François P., Di Persio J., VaNDERSChaEVE G., LefEbVRE A., Defects in Semiconductors, Ed. H. J. Von Bardeleben, Mat. Sc. Forum 10-12 (1986) 821.

[57] LefebVRe A., ANDroussi Y., VANDERSchaeVe G., Philos. Mag. Lett. 56 (1987) 135.

[58] JimeneZ-Melendo M., DJemel A., Rivière J. P., Castaing J., Defects in semiconductors, Ed. H. J. Von Bardeleben, Mat. Sc. Forum 10-12 (1986) 791.

[59] NakAda Y. and Imura T., Phys. Status Solidi (a) 103 (1987) 435.

[60] Jimenez-Melendo M., Djemel A., Rivière J. P., Castaing J., Thomas C., Duseaux M., Revue Phys. Appl. 23 (1988) 251.

[61] Gomez A. M. and Hirsch B. P., Philos. Mag. A 38 (1978) 733.

[62] Gottschalk H., Patzer G. and Alexander H., Phys. Status Solidi (a) 45 (1978) 207.

[63] Astie P., Couderc J. J., Chomel P., Quelard D. and Duseaux M., Phys. Status Solidi (a) 96 (1986) 225.

[64] Ponce F. A., Anderson G. B., HaAsen P., Brion H. G., Defects in semiconductors, Ed. Von Bardeleben, Mat. Sci. Forum 10-12 (1986) 775.

[65] Nakada Y. and IMUra T., Phys. Status Solidi (a) 102 (1987) 625.

[66] Astakhov V. M., Vasil'eVa L. F., Sidorov Yu. G. and Stenin S. I., Sov. Phys. Solid State 22 (1980) 279.

[67] MAKSimoV S. K., Ziegler M., Khodos J. J., SNIGHIRYOVA J. J., SHIKHSAIDOV M. SH., Phys. Status Solidi (a) 84 (1984) 79.

[68] Maeda K. and Takeuchi S., J. Phys. Colloq. France 44 (1983) C4-3759.

[69] Choi S., Mihara M. and NinomiYa T., Jpn J. Appl. Phys. 16 (1977) 737.

[70] Erofeeva S. A. and Osip'Yan Y. A., Sov. Phys. Solid State 15 (1973) 538.

[71] OsvenskiI V. B. and Kholodnyi L. P., Sov. Phys. Solid State 14 (1973) 2822.

[72] STEInhardT H. and HAASEN P., Phys. Status Solidi (a) 49 (1978) 93.

[73] Burle-Durbec N., Pichaud B. and Minari F., Philos. Mag. Lett. 56 (1987) 173.

[74] Yonenaga I. and Sumino K., J. Appl. Phys. 62 (1987) 1212.

[75] Burle-Durbec N., Pichaud B. and Minari F., Philos. Mag. Lett. 59 (1989) 121.

[76] Louchet F., J. Phys. France 49 (1988) 1219.

[77] Caillard D., Clement N., Couret A., ANDroussi Y., LefebVRe A. and VANDERShaeVE G., Microscopy of Semiconducting Materials 1987, Eds. A. G. Cullis and P. D. Augustus, Inst. Phys. Conf. Ser. 87 (1987) 361.

[78] Warken P. D., Pirouz P. and Roberts S. G., Philos. Mag. A 50 (1984) L23.

[79] Petroff P. M. and Kimerling L. C., Appl. Phys. Lett. 29 (1976) 461.

[80] Alexander H. and HaAsen P., Solid State Phys. 22 (1968) 27. 
[81] Yonenaga J., Onose U. and Sumino K., J. Mater. Res. 2 (1987) 252.

[82] Gilman J. J., J. Appl. Phys. 45 (1974) 508.

[83] Swaminathan V. and Copley S. M., J. Appl. Phys. 47 (1976) 4405.

[84] Mitchell T. E. and Heuer A. H., Mater. Sci. Eng. 28 (1977) 81.

[85] SzE S. M., Physics of semiconductor Devices, Eds. J. Wiley \& Sons (N.Y.) 1981, p. 19.

[86] Louchet F., Desseaux-Thibault J., Revue Phys. Appl. 22 (1987) 207.
[87] KIRKBy P. A., IEEE J. Quant. Elec. 11 (1975) 562.

[88] Friedel J., Dislocations (Paris, Pergamon Press) 1964, p. 405.

[89] Ehrenreich H. and Hirth J. P., Appl. Phys. Lett. 46 (1985) 668.

[90] Gallagher, P.C.J. Met. Trans. 1 (1970) 2429.

[91] Sato M., Sumino K. and Hiraga K., Phys. Status Solidi (a) 68 (1981) 567.

[92] Hirsch P. B., J. Microsc. 118 (1980) 33. 